\title{
The Reducing Sugars Liberated during the Bacterial Synthesis of Polysaccharides from Sucrose
}

\author{
BY W. G. C. FORSYTH* AND D. M. WEBLEY \\ Macaulay Institute for Soil Research, Aberdeen •
}

SUMMARY: Paper chromatography was used for studying qualitatively and quantitatively the reducing sugars liberated from sucrose during the synthesis of polysaccharides by certain bacteria. Glucose and fructose were the only sugars detected, varying in amount with the bacteria and with the type of polysaccharide synthesized. The results suggest that both polymerizing and hydrolytic enzymes were present.

In a preliminary note (Forsyth \& Webley, 1948) attention was drawn to the possible use of the method of paper chromatography of sugars (Partridge, 1946, 1948; Forsyth, 1948), especially when applied on a quantitative basis (Flood, Hirst \& Jones, 1947), for studying the carbohydrate metabolism of micro-organisms. This paper deals in more detail with the application of this method to the study of the reducing sugars produced from sucrose during the synthesis of polysaccharides by certain bacteria.

\section{CULTURES}

The organisms we studied were the following: Leuconostoc mesenteroides (N.C.T.C. no. 3351) and an enzyme preparation from $L$. mesenteroides strain B as used by Hehre (1946); Bacillus megatherium (A.C.T.C. strain no. 697); B. polymyxa (a strain originally isolated in Prof. Kluvyer's laboratories) (Forsyth \& Webley, 1949); Rhizobium radicicolum, no. 317; Bacillus circulans (strain no. 760, B. Krzemieniewski) smooth strain (Forsyth \& Webley, 1949).

Each of these organisms is capable of synthesizing polysaccharides from sucrose in copious amounts. Most strains of Leuconostoc mesenteroides produce copious yields of a dextran from sucrose but not from glucose or fructose or any other sugar (Tarr \& Hibbert, 1931). Bacillus megatherium synthesizes a levan from sucrose (Cooper \& Preston, 1935). Although $B$. megatherium is also capable of synthesizing a polysaccharide of a different nature from monosaccharides it does not do this on the medium used here (Forsyth \& Webley, 1949); only levan is formed. B. polymyxa synthesizes a levan from sucrose (Cooper, 1939). Forsyth \& Webley (1949) have shown that besides levan another polysaccharide composed of glucose, mannose and uronic acid units is produced by this organism. Rhizobium radicicolum synthesizes a polysaccharide containing glucose with a small amount of uronic residues from sugars (Cooper, Daker \& Stacey, 1938). Bacillus circulans, 760, synthesizes a glucose-mannose-uronic acid polymer from either sucrose or monosaccharides (Forsyth \& Webley, 1949). It has been reported that reducing sugars are

\footnotetext{
* Present address: Colonial Microbiological Research Institute, Trinidad, British West
} Indies. 
formed during the production of dextrans (Cooper \& Carruthers, 1936) and levans (Genghof, Hehre \& Neill, 1946), but no study appears to have been made on any sugars liberated during the synthesis of other polysaccharides.

\section{METHODS}

The organisms were grown in Tarr \& Hibbert's (1931) liquid medium (unless otherwise stated) with the addition of $20 \%$ yeast extract to give a final concentration of $2 \%(\mathrm{v} / \mathrm{v})$. The yeast extract was prepared by steaming a $20 \%$ suspension (fresh weight) of baker's yeast for $1 \mathrm{hr}$., decanting and filtering through a Seitz filter-disk. The sucrose concentration was $10 \%(w / v)$. A loopful of a $48 \mathrm{hr}$. culture of the required organism was inoculated into this medium (10 ml.) and the culture flask $\left(50 \mathrm{ml}\right.$.) incubated at $23^{\circ}$. The enzyme preparation from Leuconostoc mesenteroides, strain B, was prepared by the method of Hehre (1946). Three litres of the culture medium used by him were usually employed and the final precipitate taken up in $20 \mathrm{ml} .0 .025 \mathrm{M}$ citrate buffer (pH 6.3). Sucrose $(10 \%$ ) in $0 \cdot 1 \mathrm{M}$ acetate buffer (pH 5.6) was used as substrate and the enzyme-substrate mixture was made up of $2 \mathrm{ml}$. of each solution, giving an initial concentration of $5 \%$ sucrose. The enzyme-substrate mixture was incubated at $\mathbf{2 3}^{\circ}$ and the synthesized dextran precipitated by 2 volumes of ethanol.

The sugars were determined at any desired time during growth by the transfer of a definite volume of the liquid, $15 \mu \mathrm{l}$., on to a paper strip. This was initially done by means of a flame-sterilized platinum loop by weighing, but later a sterile micro-pipette was used. The micro-volume was spotted along a paper strip and the sugars chromatographed and qualitatively and quantitatively determined by the methods of Partridge (1946, 1948), Forsyth (1948), and Flood et al. (1947). An internal sugar standard was not used since it might have interfered with bacterial growth. Sucrose was detected on the paper with resorcinol (Forsyth, 1948) and estimated in the usual manner (Flood et al. 1947) after a preliminary hydrolysis with dilute oxalic acid. Sufficient concentrated oxalic acid solution was added to the sucrose extracted from the paper chromatogram to give a final concentration of $0.5 \%$. After heating on a boiling water-bath for $1 . \mathrm{hr}$. the sucrose was estimated by Somogyi's (1945) reagent in the same manner as the other sugars, using a standard sucrose solution similarly treated. Samples of the polysaccharides produced were precipitated with ethanol, hydrolysed, and the hydrolysates examined by chromatography to confirm the nature of the polysaccharides.

\section{RESULTS}

Sucrose, glucose and fructose were the only sugars detected during the growth of all the polysaccharide-synthesizing bacteria. $L$. mesenteroides produced both glucose and fructose when grown on sucrose as shown in Table 1.

The amount of glucose was, however, very small compared with fructose. In view of this result it was thought of interest to try the dextran-synthesizing enzyme as prepared by Hehre (1946) from L. mesenteroides. Using $2 \mathrm{ml}$. of 
enzyme preparation and $2 \mathrm{ml}$. of $10 \%$ sucrose in $0.1 \mathrm{M}$ acetate buffer the results shown in Table 2 were obtained.

It is clear from Table 2 that the enzyme preparation also liberated glucose as well as fructose, although in small amounts, during the synthesis of dextran. It will be seen from Table 3 that the levan-synthesizing Bacillus megatherium also produced glucose and fructose during its growth. As one might expect very much more glucose than fructose was liberated.

Table 1. Utilization of sucrose by Leuconostoc mesenteroides (N.C.T.C. no. 3351)

Grown in Tarr \& Hibbert's (1931) liquid medium $+2 \%$ yeast extract at $23^{\circ}$.

$\begin{array}{cccc}\begin{array}{c}\text { Period of incubation } \\ \text { (days) }\end{array} & \begin{array}{c}\text { Sucrose present } \\ (\%)\end{array} & \begin{array}{c}\text { Fructose present } \\ (\%)\end{array} & \begin{array}{c}\text { Glucose present } \\ (\%)\end{array} \\ 1 & 10 \cdot 00 & - & - \\ 1 & 7 \cdot 40 & 0 \cdot 92 & 0 \cdot 11 \\ 4 & 4 \cdot 50 & 2 \cdot 08 & 0 \cdot 49 \\ 6 & 0 \cdot 99 & 4 \cdot 18 & 0 \cdot 31 \\ 8 & 0 \cdot 33 & 4 \cdot 02 & 0 \cdot 14 \\ 10 & - & \mathbf{3 \cdot 9 1} & 0 \cdot 18 \\ & - & \mathbf{3 \cdot 2 2} & 0 \cdot 14\end{array}$

Table 2. Utilization of sucrose by enzyme preparation from Leuconostoc mesenteroides, strain $B$, at $\mathbf{2 3}^{\circ}$

Period of incubation (hr.)

0

24 Weight of gum (g.)
$-\overline{0.0941}$
0.1046 Sucrose present $\begin{array}{cc}\text { Fructose present Glucose present } \\ (\%)\end{array}$
$\begin{array}{cc}\mathbf{1 . 4 0} & - \\ \mathbf{1 . 6 5} & \mathbf{0 . 0 6} \\ & 0.07\end{array}$

Table 3. Utilization of sucrose by Bacillus megatherium, strain no. 697, grown in Tarr \& Hibbert's (1931) liquid medium with $2 \%$ yeast extract at $\mathbf{2 3}^{\circ}$

$\begin{array}{cccc}\begin{array}{c}\text { Period of } \\ \text { incubation }\end{array} & \text { Sucrose present } & \text { Fructose present } & \text { Glucose present } \\ \text { (days) } & (\%) & (\%) & (\%) \\ 0 & 10 \cdot 0 & - & - \\ 2 & \mathbf{3 . 5} & \mathbf{0 \cdot 6 6} & \mathbf{2 \cdot 3 4} \\ 4 & 1 \cdot 04 & \mathbf{0 . 7 2} & \mathbf{3 . 0 8}\end{array}$

Although $B$. polymyxa grew well and produced about $20 \%$ of polysaccharide, only traces of glucose and fructose could be detected after 2 or 4 days' incubation at $23^{\circ}$. Rhizobium radicicolum, $\mathbf{3 1 7}$, was grown in a liquid medium of the following composition: $\mathrm{K}_{2} \mathrm{HPO}_{4}, 0.05 \% ; \mathrm{MgSO}_{4} .7 \mathrm{H}_{2} \mathrm{O}, 0.02 \% ; \mathrm{NaCl}, 0.02 \%$; $\mathrm{NaNO}_{8}, 0.1 \%$; yeast water, $2 \%$; and sucrose, $10 \%$. This organism would not grow satisfactorily in Tarr \& Hibberts's medium. In the above liquid medium it grew well and produced copious yields of gum. However, as in the case of Bacillus polymyxa only traces of glucose and fructose could be detected in the medium. B. circulans, 760, also produced only small amounts of glucose and 
fructose in about equal quantity (2 days, glucose, $0.05 \%$, fructose $0.06 \%$; 4 days, glucose $0.04 \%$, fructose $0.08 \%$ ), although copious amounts of gum were produced and over $50 \%$ of the sucrose was utilized in 4 days.

\section{DISCUSSION}

Apart from the probable desmolytic reactions taking place it is of interest that the bacteria which produce large quantities of reducing sugars (Leuconostoc mesenteroides and Bacillus megatherium) are those which are capable of producing polysaccharide only from sucrose and not from the constituent monosaccharides. The other bacteria could use any monosaccharide liberated for the synthesis of more polysaccharide. $B$. megatherium can produce a polysaccharide from monosaccharides but not on Tarr \& Hibberts's medium (Forsyth \& Webley, 1949).

During the production of dextran by Leuconostoc mesenteroides large quantities of reducing sugars are formed and it has generally been assumed that the glucose part of the sucrose is polymerized to dextran with simultaneous liberation of the fructose moiety (Cooper \& Carruthers, 1936). Considerable interest is centred on this organism because of Hehre \& Sugg's (1942) enzymic synthesis of dextran. They considered that the formation of dextran and reducing sugars from sucrose by their enzyme preparation was consistent with the equation (Hehre, 1941):

$$
\begin{gathered}
n \mathrm{C}_{19} \mathrm{H}_{22} \mathrm{O}_{11} \\
\text { Sucrose }
\end{gathered} \underset{\left(\mathrm{C}_{6} \mathrm{H}_{10} \mathrm{O}_{5}\right)_{n}}{ }+n+{ }_{\text {dextran }}^{\mathrm{C}_{6} \mathrm{H}_{12} \mathrm{O}_{6}}
$$

That glucose as well as fructose is produced, although in small amount, by both the bacteria and by the enzyme system, suggests the presence of a hydrolytic as well as a polymerizing enzyme. The dextran produced in our experiments was hydrolysed and shown by chromatographic analysis to be indeed a polymer of glucose units only. This was done to eliminate the possibility that some levan might be produced with concurrent liberation of glucose.

Working with an enzyme, levansucrase, prepared from the cells of Aerobacter levanicum, Hestrin \& Avineri-Shapiro (1944) showed that both fructose and glucose were liberated during levan synthesis. To some extent by analogy with the equation of Hehre (1941) for dextran production, they minimized the part played by the hydrolytic enzyme which produced fructose in their system. Our showing that both dextran- and levan-producers liberate glucose and fructose suggests that the hydrolytic part of the enzyme systems may be of some importance. We confirmed that the polysaccharide produced by $B$. megatherium was composed entirely of fructose units.

The chromatographic method gives a more direct and sensitive approach to problems in this field than previous methods, since it enables the sugars to be detected, identified and estimated independently of each other at any desired time during the growth of the micro-organism.

We wish to thank: Dr Ruth E. Gordon for the culture of Bacillus megatherium and $B$. circulans; Dr Hehre for the Leuconostoc mesenteroides strain B subculture; and Dr Nutman for the culture of Rhizobium radicicolum, no. 317; used in this work. 


\section{REFERENCES}

Cooprar, E. A. (1939). Polysaccharide synthesis by the bacilli. J. Soc. chem. Ind., Lond., 58, T 229.

Cooper, E. A. \& Carruthers, A. (1936). Enzyme formation and polysaccharide synthesis by bacteria. II. Biochem. J. 30, 1001.

Cooper, E. A., Dakrer, W. D. \& Stacey, M. (1938). Enzyme formation and polysaccharide synthesis by bacteria. III. Polysaccharides produced by 'nitrogenfixing' organisms. Biochem. J. 32, 1752.

Cooper, E. A. \& Preston, J. F. (1935). Enzyme formation and polysaccharide synthesis by bacteria. Biochem. J. 29, 2267.

Frood, A. E., Hirst, E. L. \& Jones, J. K. N. (1947). Quantitative estimation of mixtures of sugars by the paper chromatogram method. Nature, Lond., 160, 8.

ForsyTH, W. G. C. (1948). Colour reagents for the paper chromatography of sugars. Nature, Lond., 161, 238.

ForsyTh, W. G. C. \& WeBLey, D. M. (1948). A method for studying the carbohydrate metabolism of micro-organisms. Nature, Lond., $162,150$.

Forsyth, W. G. C. \& Webley, D. M. (1949). Polysaccharides synthesized by aerobic mesophilic spore-forming bacteria. Biochem. J. 44, 455.

Genahor, D. S., Hehre, E. J. \& Neill, J. M. (1946). Serological reactions of levans formed from sucrose and raffinose by certain bacilli. Proc. Soc. exp. Biol., N.Y., 61, 339.

HeHre, E. J. (1941). Production from sucrose of a serologically reactive polysaccharide by a sterile bacterial extract. Science, 93,237 .

Hrmre, E. J. (1946). The enzymatic synthesis of dextran. J. biol. Chem. 163, 221.

HeHRr, E. J. \& SUGG, G. (1942). Serologically reactive polysaccharides produced through the action of bacterial enzymes. I. Dextran of Leuconostoc mesenteroides from sucrose. J. exp. Med. 75, 339.

Hegtrin, S. \& Avineri-Shapiro, S. (1944). The mechanism of polysaccharide production from sucrose. Biochem. J. 38, 2.

Parrridge, S. M. (1946). Application of the paper partition chromatogram to the qualitative analysis of reducing agars. Nature, Lond., 158, 270.

Partridge, S. M. (1948). Filter-paper partition chromatography of sugars. I. General description and application to the qualitative analyses of sugars in apple juice, egg white and foetal blood of sheep. Biochem. J. 42, 238.

Somocyi, M. (1945). New reagent for the determination of sugars. J. biol. Chem. 160,61 .

TARR, A. \& HibBert, H. (1931). Studies on reactions relating to carbohydrate polysaccharides. XXXVII. The formation of dextran by Leuconostoc mesenteroides. Canad. J. Res. 5, 414. 